\title{
The Modification of the Chinese Exchange Rate
} Policy

Its rationale, extent and recent developments

Michael Goujon et Samuel Guérineau

\section{OpenEdition}

\section{Journals}

Édition électronique

URL : http://journals.openedition.org/chinaperspectives/607

DOI : 10.4000/chinaperspectives.607

ISSN : 1996-4617

Éditeur

Centre d'étude français sur la Chine contemporaine

Édition imprimée

Date de publication : 1 avril 2006

ISSN : 2070-3449

\section{Référence électronique}

Michael Goujon et Samuel Guérineau, «The Modification of the Chinese Exchange Rate Policy », China Perspectives [En ligne], 64 | march - april 2006, mis en ligne le 01 avril 2009, consulté le 28 octobre 2019. URL : http://journals.openedition.org/chinaperspectives/607 ; DOI : 10.4000/chinaperspectives. 607

Ce document a été généré automatiquement le 28 octobre 2019

(c) All rights reserved 


\section{The Modification of the Chinese Exchange Rate Policy}

Its rationale, extent and recent developments

Michael Goujon et Samuel Guérineau

1 On 21st July 2005, the Chinese Central Bank revalued the yuan from 8.27 to 8.11 per US dollar. This small revaluation (2.1\%) was accompanied by an official modification of the exchange rate system. The authorities announced that "the yuan will be no longer pegged to the US dollar" and that "China will reform the exchange rate regime by moving into a managed floating exchange rate regime based on market supply and demand with reference to a basket of currencies"2. They did not publish details of the composition of this basket.

2 The revaluation occurred during an intense two-year long debate, among scholars and political leaders about Chinese exchange rate policy, since 2003. American policymakers have often complained that the yuan has long been significantly undervalued, giving China an unfair trade advantage. Thus, China is blamed for a "currency manipulation" that induces job losses in the United States, Japan, Europe and other Asian countries, threatening world economic equilibrium. The yuan being revalued, one might think, is due to China yielding to this international pressure (and recognising its responsibility in the imbalance in world trade).

3 This paper suggests that this interpretation is simplistic and misleading. First of all, it has been demonstrated that for 25 years the Chinese exchange rate policy has aimed at both internal and external targets-and not only export competitiveness ${ }^{3}$. Consequently, both must be taken into account in interpreting any exchange rate policy modification. Following this, this paper looks at the rationale behind the recent modification of the Chinese exchange rate policy in reviewing the two debates on the need for revaluation and greater flexibility. The last section explores the short-run impact of this decision.

The debate on the revaluationIs the yuan undervalued?

4 To provide empirical elements to the debate on the undervaluation of the yuan, numerous studies have recently been dedicated to the assessment of misalignment of 
the yuan. This series of studies since 2003 was preceded by another series in the late 1990s, which attempted to assess the sustainability of the peg to the dollar after the Asian financial crisis (an overvaluation was then suspected). As expected for a rapidly transforming economy, the estimated size of misalignment differs significantly across studies, and some estimations show almost perfectly reversed evolutions ${ }^{4}$.

From Figure 1 where these estimations are reported, several general results may however be emphasised: i) The initial overvaluation progressively disappeared during the 1980s; ii) The exchange rate was close to its equilibrium value or slightly undervalued at the beginning of the 1990s; iii) The nominal devaluation induced a $10 \%-30 \%$ real undervaluation in 1994; iv) Undervaluation was partially or fully erased between 1995 and 1997; v) Since 1998, deflation and rapid economic growth have led to a new drift of undervaluation. While there is major consensus on the undervaluation of the current yuan, the range of the different misalignment estimations is very large, from $10 \%$ to $60 \%$. The critical point is the diagnostic on the $1997-98$ period: the current undervaluation is expected to be large (narrow) if one considers that the exchange rate was already undervalued (near equilibrium) in 1997-98.

Which interpretation is the more convincing? Let us start with the main arguments of a large undervaluation. The first argument is trade dynamism. The growth of Chinese exports is impressive (for instance, merchandise exports increased by $33 \%$ in the first half of 2005) and trade surpluses with the United States and the European Union are huge (respectively US $\$ 162$ billion and US $\$ 100$ billion in 2004). These basic features are systematically emphasised by foreign policy-makers. However, one can suggest that trade balances would be more relevant than exports and then recognise that Chinese imports also grew rapidly last year. Moreover, one can consider that the overall trade balance would be more relevant than bilateral trade balances, and then observe that a large part of the Chinese trade surplus with OECD countries is offset by trade deficits with Asian countries.

Regarding the current account, China has run surpluses for almost ten years (3\% of GDP in 2002 and 2003), which supports the undervaluation assertion. This situation is not common for an emerging economy, even more so when it regularly exhibits signs of overheating (which increases demand for imports). Furthermore, Morris Goldstein considers that the "underlying" surplus is larger than the actual surplus considering the overheating effect and the lagged effect of the earlier real depreciation ${ }^{5}$. Since China runs capital account surpluses (which is common for an emerging economy), the "equilibrium" current account should exhibit a deficit. Consequently, there exists a huge gap between the "underlying" and the "equilibrium" current account balance, suggesting a large real undervaluation.

8 A large undervaluation would also be the main source of the dramatic accumulation of foreign exchange reserves (from US $\$ 150$ billion in 2001 to US $\$ 750$ billion in mid-2005). The central bank had indeed to buy huge amounts of dollars that would have induced the exchange rate to appreciate under floatation. 


\section{Real Effective Exchange Rate and Yuan Misalignement}

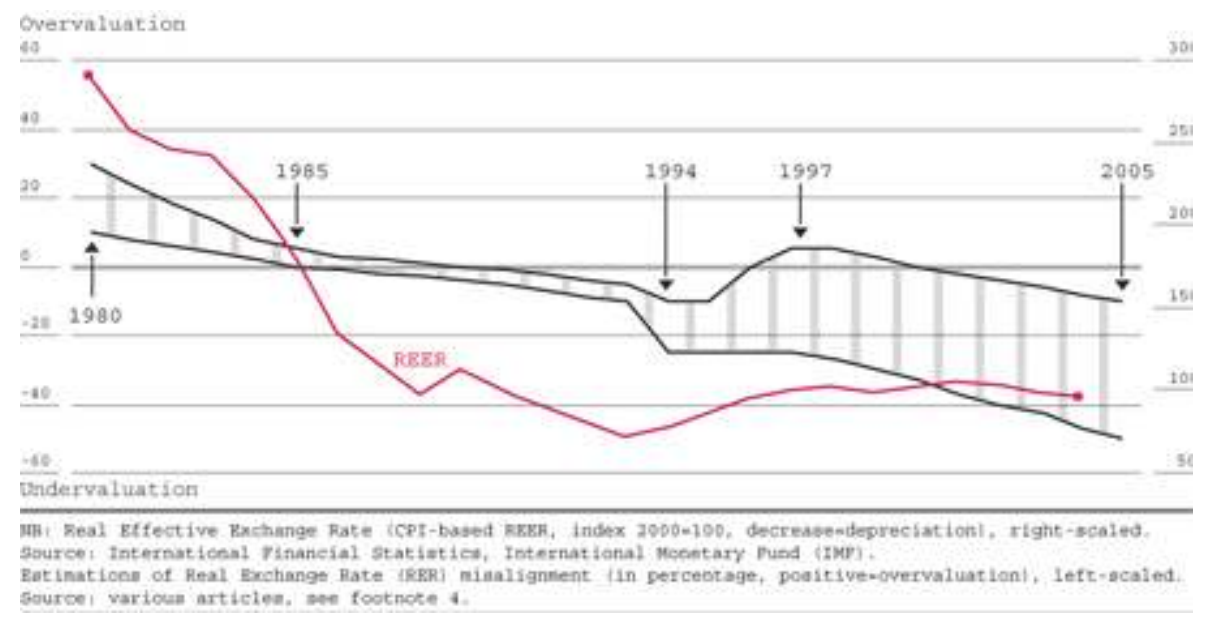

What reasons are there to be sceptical about the existence of a large undervaluation? The weaker argument for a large undervaluation is the bilateral surplus with the United States since, as noted earlier, China runs large deficits with Asian countries. In fact, this particular structure of trade balances has been strongly induced by a structural change in the division of labour in East Asia, i.e., the relocation in China of a part of the production of the emerging economies which grew rapidly in the 1970 and 1980s. This relocation has simultaneously raised imports from Asian countries and exports to OECD countries 6 .

10 Another structural factor of China's competitiveness is the almost infinite pool of labour (underemployed workers in the countryside and workers laid-off from stateowned enterprises), which explains low (and flexible downwards) wages.

11 A good illustrative example of a structural advantage that China has over other emerging economies on international markets is in textiles and garments, as dramatically revealed since the end of the MultiFibre Agreement (MFA) on January 1st $2005^{7}$. This is illustrated in Table 2 reporting EU trade statistics for the first five months of 2005, where it is clear that Chinese exports tend to replace the exports of other emerging economies.

\section{European Union Textiles and Clothing imports}

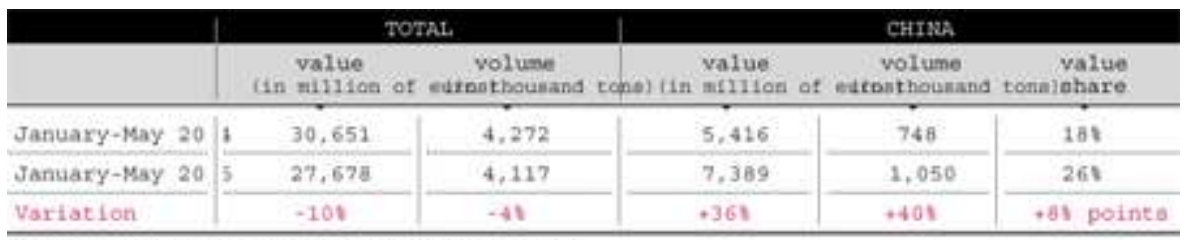

Sourcei ru trade otatiotics at http://europa.eu. Int?

12 Third, the current undervaluation should only come from a recent appreciation of the equilibrium real exchange rate because: i) the Real Effective Exchange Rate (REER) is almost stable since 1998 as reported in Figure 1; and ii) 1998 was marked by depreciation tensions, suggesting the exchange rate was not undervalued in this year. An appreciation of the equilibrium Real Exchange Rate (RER) should come from relative productivity gains (economic growth and reforms) according to the Balassa-Samuelson effect. However, the imports liberalisation induced by its accession to the World Trade Organisation inversely calls for a depreciation of the equilibrium RER (since it would 
deteriorate China's trade balance for any level of the exchange rate), even if the end of MFA reduces the net effect of trade policy changes. It is reasonable to think that the productivity gain effect would be greater than the net effect of trade policy, but would not, under reasonable assumption, lead to a rapid and huge appreciation of the equilibrium RER 8 .

Fourth, the equilibrium RER is supposed to ensure simultaneously external and internal equilibrium but most studies have underemphasised this second condition. High underemployment, as experienced by China, rather suggests a RER overvaluation according to internal equilibrium condition. Consequently, studies that focus only on the external condition simply overstate undervaluation'. The exchange rate is not the instrument to be preferred against underemployment but a country that experiences high underemployment cannot, arguably, afford a massive revaluation.

Last, a huge undervaluation is not compatible with the trends in the non-deliverable forward market for Chinese yuan (in the Hong Kong or Singapore forex markets). First, appreciation expectations were not dominant until November $2002^{10}$. Second, the observed discount on the yuan forward rate has remained very low since then $(1,5 \%$ for the one-year forward contract) until the recent revaluation. Even considering the distortion due to the peg, it is hard to believe that the "real" undervaluation is, say, twenty or thirty times greater than the forward rate discount.

Considering these arguments-but keeping in mind the difficulty to have a clear-cut opinion on exchange rate misalignment-the "moderate undervaluation" hypothesis (10\%-15\%) seems finally more convincing. Moreover, being a developing country, China may reasonably keep a competitive cushion to manage external shocks. Therefore, a smaller revaluation than the 10\%-15\% range would be acceptable by China and foreign trade partners. But what should be expected from such a revaluation?

The main argument: the reduction of trade imbalances

China is blamed for undervaluation of the yuan, which is assumed to exacerbate international trade imbalances (in particular the US trade deficit). Therefore, the reduction of trade imbalances is the main benefit to be expected from the revaluation. However, such a result depends on the very nature of trade imbalances and on the value of trade price-elasticities.

Let us start with China. As noted earlier, exports dynamism is certainly explained as much by structural factors (wage flexibility) as by the exchange rate policy. Moreover Chinese exports have a high import content due to the export-processing sector ${ }^{11}$. Therefore the China trade surplus is unlikely to be very sensitive to exchange rate fluctuations ${ }^{12}$.

Do empirical studies find low price-elasticities? Unfortunately, export price-elasticity estimations based on recent data are scarce and heterogeneous ${ }^{13}$. Since these estimations cannot integrate the structural competitiveness of China, one could expect that the true elasticities are in fact smaller than estimated, or are non-linear (an appreciation-induced drop in exports would be smaller than a depreciation-induced increase in exports).

What could be the impact of revaluation of the yuan on OECD countries? China being the source of around 6\% of OECD total imports, and assuming a unitary price-elasticity of OECD imports of Chinese products, a $10 \%$ revaluation of the yuan would lead to only a $0.6 \%$ reduction of OECD imports. Moreover, the reduction of imports volume would be 
fully offset by the increase in price with actually no effect on trade balance. In fact, any improvement in trade balance should then come from the expansion of OECD exports to China. Exports to China represent $4 \%$ of total US exports, assuming a unitary priceelasticity, US exports would be raised by $0.4 \%$ following a $10 \%$ revaluation, i.e. US $\$ 4.6$ billion as opposed to a US current account deficit of US $\$ 618$ billion in 2004. According to Jonathan Anderson, even a large yuan revaluation would have a limited impact on the US trade deficit, which is more affected by trade competition with the European Union and Japan ${ }^{14}$. In the same vein, Ronald MacKinnon and Joseph Stiglitz point out that the USA will run current account deficit as long as US private and public savings are very low, whatever the Chinese exchange rate policy ${ }^{15}$.

Recognising the small direct impact of the yuan revaluation, some authors emphasise the possibility of contagion ${ }^{16}$. If the other Asian countries (also blamed for undervaluation) follow China's decision to revalue, the overall impact of the yuan revaluation on OECD trade balances would be greater. Morris Goldstein suggests that a $20 \%$ yuan revaluation could lead other Asian emerging economies and Japan to allow a $15 \%$ revaluation of their currencies ${ }^{17}$. Agnès Bénassy and Amina Lahrèche-Revil discuss a case where most Asian countries follow a $10 \%$ yuan revaluation ${ }^{18}$. However, they note that Asian countries would be certainly less prompt to follow an appreciating yuan (the current scenario) than a depreciating yuan (recalling the fear of the "domino effect scenario" during the Asian financial crisis).

21 At last, the expected impact of a $10 \%$ yuan revaluation on the intra-Asian trade would be even weaker, given the growing importance of the vertical intra-industry integration ${ }^{19}$. One cannot ignore however the impact of the revaluation on third markets (EU and USA) where China's products would be less competitive.

In conclusion, the Chinese responsibility in international trade imbalances and consequently, the capacity of a yuan revaluation to significantly reduce trade imbalances seems to be highly overstated. By contrast, China itself is obviously the most sensitive to a large revaluation, which gives the Chinese authorities room to determine exchange policy according to their own objectives, rather than to a hypothetical effect on trade imbalances. Thus the next question is whether the revaluation has a positive impact on China.

Other arguments: some conflicting effects

Some authors suggest that revaluation will serve China's self interests ${ }^{20}$. The main advantage in avoiding an undervaluation of the yuan would be to dampen hot money inflows (probably about US $\$ 50$ billion in 2003). Indeed, these inflows lead to a rapid accumulation of foreign exchange reserves that has some awkward macroeconomic effects $^{21}$. On one hand, the amount of reserve accumulation that is not sterilised produces a surge of money supply ( $+20 \%$ in 2003), which may have two main adverse effects: i) it may give rise of inflation pressure through an increase in bank loans and investment; ii) it may make the banking reform harder by giving banks an excessive liquidity, which reduce the incentives to improve credit allocation inducing a new surge of non-performing loans. On the other hand, the fraction of such an increase in reserves that is sterilised (almost one half of the total in 2003) induces a significant cost (interest payment on sterilising instruments such as government bond).

24 An indirect benefit from revaluation would be to lessen the risk of a revival of protectionism from countries running bilateral trade deficits with China (mainly the United States, Europe and Japan). 
However, revaluation is potentially costly for China. One of Chinese policy-makers concerns is the risk of deflationary pressures, though mitigated by a current rise in inflation (almost $4 \%$ in 2004). However, one cannot exclude the possibility that a large revaluation may put downward pressure on wages, causing a fall in domestic demand (already weak) and output.

Financial stability is also of concern. Revaluation is automatically reducing the value of dollars assets held by commercial banks and the Central Bank, with the latter being the main loser given its net foreign assets of US $\$ 750$ billion. Additional destabilising effects on the financial sector may be expected if the revaluation is carried through a flexibilisation of the exchange rate, but this point is related to the exchange rate regime, and not to the revaluation itself (see below).

Another undesirable effect might come from the strengthening of investment in the non-tradable sector and particularly in the already speculative real estate. In addition, the Chinese reluctance to revaluate may be linked to the political will to promote the development of local firms, of which the productivity is probably lower than that of foreign funded enterprises and joint-ventures.

8 At last, financial markets response to revaluation (and thus future speculative inflows) is to be clearly anticipated. The size of the revaluation needed to cancel appreciation expectations may be too large to be economically affordable.

To sum up, the above analysis suggests that China could bear a moderate revaluation of, say, $10 \%$, i.e. without incurring unacceptable costs on both external and internal sides.

However, such a revaluation cannot be considered a unilateral effort on China's part to reduce international trade imbalances. Since China is not involved in an international monetary arrangement, any co-operative action has to be negotiated between sovereign partners (as it has been done in the 1980s between the United States and Japan) and not unilaterally required by one of them. In short, as the Chinese prime minister Wen Jiabao recalled ${ }^{22}$, China's government freely determines its own exchange rate policy. Moreover, considering that the responsibility of international imbalances is collective, why should China (a developing country with a per capita income of around US $\$ 1,000)$ take a greater share of the adjustment costs than the high-income economies (above US $\$ 25,000$ per capita)?

The debate on flexibility

31 Many agree that the yuan exchange rate system needs greater flexibility. Currently, the main drawback of keeping the peg on the dollar is linked to short-term capital inflows. In a context of appreciation expectations, and though the capital account is not officially liberalised, these inflows are sizeable. The Chinese monetary authorities thus need to sterilise a large share of these inflows to keep monetary growth under control. The sterilisation is carried out through the sale of government bonds (or central bank bills), and induces a significant cost, corresponding to the gap between the average return on international reserves and the interest rate paid on government bonds ${ }^{23}$. As China is opening up to the world economy, financial integration is increasing (even if existing restrictions on capital flows slow down integration), which under a fixed exchange rate, is not compatible with an independent monetary policy. Since China needs monetary policy for stabilisation purposes, the transition toward a greater flexibility seems unavoidable ${ }^{24}$. This view is predominant among scholars and economic 
newspapers in OECD countries ${ }^{25}$. Moreover, if China would liberalise the capital account, the need for flexibility would be even greater.

Several authors however think that the dollar peg remains the best available option for China and other East Asian countries, both for trade and financial concerns ${ }^{26}$. Trade intensity is a basic argument for pegging: The United States is still a major trade partner of East Asian countries (even if share has slightly declined over the last two decades), and of China (in 2004 the United States accounted for $15.2 \%$ of total Chinese trade, with $22.8 \%$ for exports, $7.7 \%$ for imports). However several arguments give stronger support to the peg. First, the US dollar is not only used for trade with the United States, but is also the prevailing currency for invoicing trade in East Asia (except for direct trade with Japan which is invoiced in yen). Furthermore, the benefits of the dollar peg are reinforced by the lack of foreign exchange rate hedging instruments (the only way to hedge foreign exchange risk with yuan is to rely on the offshore non-deliverable forward markets located in East Asian financial centres, mainly Hong Kong and Singapore ${ }^{27}$.

33 As for trade, the US dollar is the main currency for invoicing capital flows in East Asia since domestic financial markets are underdeveloped. In particular, the majority of East Asian economies are unable to borrow internationally in domestic currency. Nevertheless, since they have run current account surpluses, most emerging East Asian countries, and particularly China, are currently net creditors, thus accumulating a large stock of dollar claims. Ronald McKinnon named this particular currency mismatch the "conflicted virtue" syndrome. This mismatch leads to appreciation pressures on domestic currencies, inducing the risk of loss on dollar claims value, thus pushing governments to the dollar peg. Since a hard peg commitment is too risky and regional co-ordination is far to be efficient, soft dollar peg remains an attractive option $^{28}$.

Moreover, greater exchange rate flexibility may produce serious disturbances in the Chinese financial sector, which is not prepared to manage foreign exchange risk. Admittedly, the restrictions on capital account transactions may mitigate these risks in the short run, and give time to improve banking competences in this field. Nevertheless, paying great attention to macroeconomic stability and recognising the financial sector vulnerability, the Chinese government is greatly reluctant to significantly increase yuan flexibility.

35 To increase exchange rate flexibility, four main options can be listed, ranging from the more to the less flexible: free floating, dollar peg within a widened band, basket peg, and adjustable dollar peg. Considering the fragility of the financial sector, free floating is not a feasible option in the short term (although suggested by US treasury secretary John Snow in 2003).

36 Morris Goldstein and Nicholas Lardy suggested a two-stage reform. In a first stage, a widening of the band (from less than $1 \%$ to $5 \%-7 \%$ ) would be carried out simultaneously with a $15 \%-25 \%$ revaluation ${ }^{29}$. In the second stage, when the banking system would be strong enough to allow a significant liberalisation, the foreign exchange regime would move to floating. Widening the band is also advocated by $\mathrm{Lu}^{30}$, while Williamson thinks that the basket peg would be the first stage of foreign exchange reform ${ }^{31}$.

37 Among the three short-run "feasible" options, the Chinese authorities have chosen a basket peg, so far without information about the composition of the basket. A logical composition would include the three main international currencies but giving more 
weight to the US dollar. Williamson however derives an "optimal" five-currency basket from the China trade structure ${ }^{32}$ : US dollar $(20,9 \%)$, euro $(22,9 \%)$, yen $(25,1 \%)$, and Hong Kong dollar $(19,3 \%)$ and Korean won $(11,8 \%)$. At the regional level, Williamson advocates the adoption of a peg to a common basket by East Asian countries and using the same methodology, the optimal basket would be US dollar $40 \%$, euro $30 \%$ and yen $30 \%$. Recently, the Chinese monetary authorities indicated that the basket mentioned in the July 21st decision contains more than three currencies, i.e. not only the three major currencies, but probably also the Korean won and the Singapore dollar and other Asian currencies with smaller weights.

What has occurred since July 21st?Is the exchange rate really flexible?

To date, the main target of the July 21st decision-to slow down hot money inflows-seems to have been reached. Did it allow the Central Bank to significantly improve actual flexibility? There is some purposeful ambiguity in the announcement of the new foreign exchange regime on July $21 \mathrm{st}^{33}$. Allowing small and discretionary exchange rate adjustments does not imply a loss of control over exchange rate fluctuations. The modification of foreign exchange regime is actually likely to have a slight impact if adjustments are scarce. A crucial point is the use of the band mechanism, since the daily trading band of $0.3 \%$ a day theoretically allows a significant appreciation, even in the short term. A few days after the revaluation, the Financial Times calculated that a $15 \%$ appreciation could be attained in less than two months and a half, and financial markets seemed to believe in the gradual appreciation scenario. In Singapore, the one-year yuan non-deliverable forward rate then rose to 7.64 per dollar (corresponding to a $6 \%$ appreciation over the next 12 months). Some financial institutions (Merrill Lynch or BNP Paribas) forecasted a significant appreciation by the year-end (respectively RMB7.5 and RMB7.9 per dollar) ${ }^{34}$. However, while initially having declared that the revaluation is only an initial step, a few days later the Central Bank denied that there is any plan for further revaluation.

Actually the Chinese exchange rate has experienced an almost unperceivable revaluation trend since July 21st (from the revaluation rate of RMB8.11 per dollar, it reached RMB8.10 at the beginning of August and RMB8.08 at the beginning of September). The exchange rate stabilised at RMB8.07 at the end of October until December, which corresponds to a $0.5 \%$ revaluation since July 21st. In short, the scenario of a gradual appreciation seems to move away, or at least to be postponed for several months. On September 30th-a few days after the G7 meeting during which the United States and the European Union urged China to free the yuan further-the Central Bank announced a widening of the yuan's trading band against the non-dollar currencies. The yuan's trading band against currencies such as the euro and the yen is then doubled to \pm 3 per cent. As in July, most foreign policy-makers commented favourably this decision, although suggesting that the move was far from sufficient.

At this point, the move to flexibility is too modest to produce any significant effect and, on statistical grounds, the de facto exchange rate regime is still to be classified as a dollar peg, though less hard than it used to be ${ }^{35}$. However, this "pseudo-flexibilisation" has the same virtue as the "mini-revaluation", it makes harder to criticise China for not contributing to solving world trade imbalances. This move is however probably not only a diplomatic decision; it also aims at signalling that the move towards a more flexible exchange rate regime is officially initiated.

Is there a contagion effect among Asian currencies? 
41 Table 2 reports the very short-run response to the yuan revaluation of ten Asian exchange rates since July 21st. Exchange rate responses have varied, depending on the exchange rate regime and, on circumstances ${ }^{36}$. For instance, maintaining a currency board arrangement, the Hong Kong SAR has not seen any significant move in the HK Dollar exchange rate at 7.77 per US dollar (within the 7.75-7.85 trading band introduced in May 2005). One can roughly classify the remaining countries as follows: The yen and the baht have shown an almost complete absorption of the yuan revaluation even after eight weeks; The won and the Singapore dollar (and to a lesser extent the ringgit) have shown an almost complete absorption within two weeks but have tended to recover progressively their past level since then; The rupee, the rupiah, the peso and the Taiwan dollar have been affected by the revaluation announcement but only soon after when they demonstrated independent fluctuations. Three months later, only the Thai baht remains tied to the yuan.

\section{Incremental Appreciation of Asian Currencies as Compared to Appreciation in the Yuan}

\begin{tabular}{|c|c|c|c|c|c|c|c|c|c|c|c|}
\hline & & Yen & $\begin{array}{c}48 \\
5\end{array}$ & Rupee & Rupiah & Ringgit & tPeso: & Singapo & rwon & $\begin{array}{c}\text { Talwan } \\
\$\end{array}$ & Baht \\
\hline Revaluation if & aguly $210 t$ & 126 & 5,6 & 45 & 16 & $-0,3$ & 16 & 105 & 33 & -6.5 & 88. \\
\hline 1 day after & July $22^{n a t}$ & 97 & 2,6 & 7.2 & 15 & 24 & 38 & 89 & 101 & 53 & 86 \\
\hline 2 daye after & Juily $25^{\mathrm{ch}}$ & 00 & 2,6 & 0.6 & 11 & 62 & 39 & 80 & 138. & 31 & 91 \\
\hline 1 week after & July $2 \mathrm{gts}^{\mathrm{ta}}$ & 47 & 2,2 & 13 & $-8 \cdot a$ & 62 & -19 & 68 & 70 & 0 & 39 \\
\hline 4 weeks afte: & Auguast 18' & 2117 & 4,8 & $-4,1$ & -61 & 38. & $-0,8$ & 64 & 87 & -31 & 90 \\
\hline 8 weeks afte: & September & $5 \% 09$ & 9,8 & .33 & -81 & 32 & $-4,4$ & 25 & 66 & -118 & 113 \\
\hline 3 months aft. & $\mid$ rectober $2 \mid$ & at -89 & 12,3 & -143 & -76 & 27 & 12,5 & -26 & -63 & -221 & 124 \\
\hline
\end{tabular}

42 An increased exchange rate flexibility or volatility in the region would have been expected following the July 21st decision. Surprisingly however, almost all exchange rates demonstrated an unchanged or even a smaller volatility after July 21 st, except the Indian rupee, the Indonesian rupiah and the Taiwan dollar (see Table 4).

\section{Exchange Rate Variance Before and After the Yuan Revaluation}

\begin{tabular}{|c|c|c|c|c|c|c|c|c|c|c|c|}
\hline & ruan & Yen & $\begin{array}{c}4 \mathrm{KK} \\
\$\end{array}$ & Rupee & Rupiah & Ringgi & tPeso. & singapo & rewon & Taiwan & Baht \\
\hline Pre-varian & le $\quad 0.00$ & 4.77 & 0.02 & 0.05 & $3+84$ & 0.00 & 1.87 & $|1,20|$ & 2.61 & 0.76 & 5.05 \\
\hline Post-varia: & ce 0.03 & 3.06 & 0.01 & 1.44 & 5.71 & 0.07 & 0.16 & $\mid 0.79$ & 1.40 & 4.27 & 0,28 \\
\hline
\end{tabular}

$\mathrm{MB}$. Varisnce of currency exchasge rate index againat the do11sx, 65 days before and 65 days after tbe July

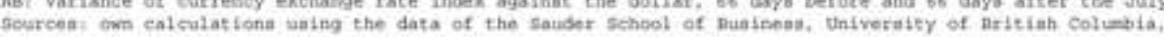

Admittedly, very short-run moves in some exchange rates gave strength to the contagion scenario (particularly Malaysia, by scrapping its peg to the dollar and allowing the ringgit to appreciate right after China's decision ${ }^{37}$ ). However, one can guess that this would be a simplistic interpretation. In fact, currently almost all countries have experienced an economic and financial recovery since the Asian financial crisis and the turbulent year of 2001, underpinning the move to greater exchange rate flexibility. The yuan revaluation announcement may have created a favourable regional context, and, for instance, Malaysian authorities used this opportunity to abandon the peg with less risk of market speculation. In conclusion, even if an instantaneous impact was noticeable across all Asian countries, the contagion effect vanished rapidly, except for the Thai baht.

Has there been an impact on the economy? 
One could consider that the time passed is too short to feel the effect of the revaluation. However, some rough information could be extracted from short-term situation indicators and from economic forecasts before and after the revaluation. Right after the revaluation, comments mainly support the view of a forthcoming negative impact on activity and price ${ }^{38}$. Two months on, this negative impact has less support. Concerning the external accounts, export performance has not been affected by the July 21st decision (see Tables 5 and 6). Furthermore and surprisingly, medium-term expectations about the current account show even more improvement compared to 2004 (US $\$ 53$ billion or $4.2 \%$ of GDP), the International Monetary Fund being the most optimistic.

\section{Actual Monthly Trade}

\begin{tabular}{|c|c|c|c|}
\hline & \multicolumn{3}{|c|}{$\begin{array}{l}\text { BeforeAfter } \\
\text { revaluationevaluation }\end{array}$} \\
\hline & July & August & Septembe \\
\hline $\begin{array}{l}\text { Exports } \\
\text { growth } \\
(y-0-y \quad 8)\end{array}$ & 28.7 & 32.1 & 25.9 \\
\hline $\begin{array}{l}\text { Trade } \\
\text { surplus } \\
\text { (US\$ billion) }\end{array}$ & 10.5 & $10.0 *$ & 7.6 \\
\hline
\end{tabular}

\section{Current Account Forecasts}

\begin{tabular}{|c|c|c|c|c|}
\hline & & Before revaluation & After revaluation & Gap \\
\hline \multirow{2}{*}{$\begin{array}{l}\text { Aalan Development Bank } \\
\text { (Apt1) and Oetaber) }\end{array}$} & 2005 & 1.2 & 4.7 & . 3.5 \\
\hline & 2006 & 0.4 & 3.6 & +3.2 \\
\hline \multirow{2}{*}{$\begin{array}{l}\text { International Monetary Pu } \\
\text { (May and soptenber) }\end{array}$} & A2005 & 4 & 6.1 & +2.1 \\
\hline & 2005 & 3,7 & 5,6 & $\cdot 1.9$ \\
\hline \multirow{2}{*}{$\begin{array}{l}\text { Dresdiner Bank } \\
\text { (Apr1I aed Septenber) }\end{array}$} & 2005 & 3,5 & 3.6 & 0.0 .1 \\
\hline & 2005 & 3,4 & 3.7 & $\cdot 0.3$ \\
\hline
\end{tabular}

Considering this impact on trade, it is not surprising that economic activity would not be hurt by the recent revaluation (see Tables 7 and 9). There is no short-run effect on industrial production in August (even more, industrial production growth in August, $+16.0 \%$, would exceed the latest projection of $+15.7 \%$ ). Moreover, whatever the source, the growth outlook has been revised upwards since the revaluation for the entire year of 2005 (from 0.2 to 1.0 percentage point) and has been unchanged for $2006^{39}$. 


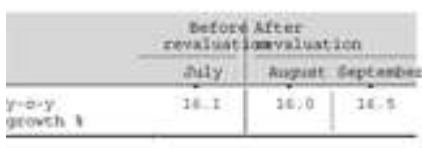

9. Actual Monthly Inflation

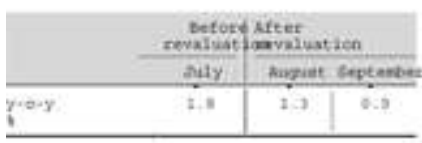

Before revaluation, 2005 inflation forecasts ranged from $2.5 \%$ to $3.6 \%$, showing a downward trend from the 2004 peak of $3.9 \%$. An appreciation of the exchange rate should have put further downward pressure on domestic prices. The overall picture does not depart from this theoretical outcome (see Tables 8 and 10. The year-on-year CPI increase in August was down by 0.5 percentage point from July. Post-revaluation revised forecasts for the entire year are effectively weaker now ${ }^{40}$. During the last quarter of 2005, all 2005 inflation forecasts are lying within the $2.0 \%$ to $3.0 \%$ range.

\section{Annual GDP Growth Forecasts}

\begin{tabular}{|c|c|c|c|c|}
\hline & & Before revaluation & After revaluation & Gap \\
\hline People's Bank of China & 2005 I & 9.0 & 9.2 & +0.2 \\
\hline \multirow{2}{*}{$\begin{array}{l}\text { Asian Development Bank } \\
\text { (April and October 2005) }\end{array}$} & 2005 & 9,5 & 9.2 & +0.7 \\
\hline & 2006 & 8,7 & a. 6 & +0.1 \\
\hline \multirow{2}{*}{$\begin{array}{l}\text { International Monetary } P \\
\text { (May and Soptenter 2005) }\end{array}$} & ta2005 & 8.5 & 9.0 & +0.5 \\
\hline & 2005 & 3.0 & 8.2 & .0 .2 \\
\hline \multirow{2}{*}{$\begin{array}{l}\text { Dresdner Bank } \\
\text { (April and septenter 2005) }\end{array}$} & 2005 & 8,0 & 9,0 & $\cdot 1.0$ \\
\hline & 2006 & 3. 0 & 8.0 & 0.0 \\
\hline
\end{tabular}

\section{Annual Inflation Forecasts}

\begin{tabular}{|c|c|c|c|c|}
\hline & & Before revaluation & After revaluation & Gap \\
\hline People's Bank of China & 20051 & 2.7 & 2.0 & -0.7 \\
\hline \multirow{2}{*}{$\begin{array}{l}\text { Asian Development Bank } \\
\text { (Aprit and October 2005) }\end{array}$} & 2005 & 3.6 & 2.5 & -1.2 \\
\hline & 2006 & 3.3 & 2,6 & -0.7 \\
\hline \multirow{2}{*}{$\begin{array}{l}\text { International Monetary Pu } \\
\text { (May and soptenter 2005) }\end{array}$} & 42005 & 3.0 & 3.0 & 0.0 \\
\hline & 2005 & 2.5 & 3.8 & +1.3 \\
\hline \multirow{2}{*}{$\begin{array}{l}\text { Dresdiner Bank } \\
\text { (ApriI and September 2005) }\end{array}$} & 2005 & 3.5 & 2.5 & -1.0 \\
\hline & 2006 & 3.0 & 2.0 & -1.0 \\
\hline
\end{tabular}

47 While, as expected, a price deceleration has been slightly reinforced, a surprising outcome is that external account and growth expectations have improved since the revaluation. These results, arguably, may be explained by the small size of the 
revaluation that was unable to lead to a dramatic break in the previous macroeconomic trends.

By revaluing its currency, China did not yield to international pressure. Admittedly, the Chinese government took into account the political benefit of such an action, since this will mitigate protectionist pressure for a few months. However, its decision was essentially driven by the wish to dampen the surge of hot money, attracted by revaluation expectations. One might have expected that the revaluation was too small to fight these expectations. However, the Central Bank repeated denials that a further revaluation may succeed in curbing short-term capital inflows ${ }^{41}$.

To date, this is the main effect of the July 21st decision, since other expected effects are limited. First, the lessening of exchange rate tensions is neither large nor old enough to lead the Chinese government to speed up the move to de facto flexibility. Second, the impact of yuan revaluation on Asian currencies has been modest and transitory. Last, the yuan's revaluation has not modified the previous macroeconomic trends of the Chinese economy (increasing current account surpluses, sustained growth and deceleration of prices). In a broader perspective, the most important effect of the July 21st decision might be to signal the official start of the move to flexibility, even if this move is slower than it was expected two months ago.

\section{NOTES}

1. Earlier versions of this paper benefited from participant comments at the CES/CEFC $1^{\text {st }}$ Biannual International Conference on Transition and Economic Development in China in Shanghai, China (September 10th-11th 2005) and at the Centre d'études et de recherches sur le développement international (CERDI) $5^{\text {th }}$ International Conference on the Chinese Economy in Clermont-Ferrand, France (October 20th-21st 2005).

2. People's Bank of China. Public announcement (www.pbc.gov.cn/english/).

3. Samuel Guérineau and Sylviane Guillaumont Jeanneney, "Politique de change et inflation en Chine", Revue d'Economie Politique, 113(2), 2003, p. 232, and Samuel Guérineau, "Chinese Exchange Rate Policy Goals: Estimation of a Reaction Function (1985-1994)", CERDI, mimeo, 2002.

4. An analytical table of 15 articles providing estimations of misalignment of the yuan is given in a previous version of the paper available on the CERDI website as a working paper at http://www.cerdi.org/Publi/ED_Detail.asp?Id=739.

5. Morris Goldstein, “Adjusting China's exchange rate policies”, Institute for International Economics, Working Paper No. 04-1, 2004.

6. Guillaume Gaulier, Françoise Lemoine and Deniz Unal-Kesenci, “China's integration in East Asia: production sharing, FDI and high-tech trade", Centre d'études prospectives et d'informations internationales (CEPII), Working Paper No. 2005-09, June 2005.

7. Studying the relative competitiveness between China and Vietnam on garment, Demurger and Goujon (2001) find that the advantage of Chinese firms seems to be more in the domestic industrial structure and environment than in labour costs and 
productivity: Chinese industries are more integrated (various intermediary inputs are produced locally in China), the business environment in China seems to be more propitious to the development of the production sector with high saving and investment ratios, abundant and skilled labour and support policies from the local administration. Constraints such as regulation opacity and administrative clumsiness exist in China but are relieved by an advanced economic decentralisation. See Sylvie Démurger and Michael Goujon, "Compétitivité de l'économie vietnamienne comparée à celle de la Chine", CERDI report, in Forum Franco-Vietnamien Economique et Financier, ADETEF CD-Rom, 2001, 67 pp.

8. Official data suggest that productivity gains decelerated in the second half of the 1990s, see Samuel Guérineau and Sylviane Guillaumont Jeanneney, "Deflation in China", China Economic Review, 16(4), 2005, pp. 336-363.

9. The Fundamental Equilibrium Exchange Rate method integrates the internal equilibrium condition. See for instance Virginie Coudert and Cécile Couharde, "Real Equilibrium Exchange Rate in China: Is the Renminbi Undervalued?", CEPII, Working Paper No. 1, January 2005. Nevertheless, internal equilibrium is assessed through an estimation of the output gap, which ignores labour market disequilibria.

10. Hung-Gay Fung, Wai K. Leung, and Jiang Zhu, "Nondeliverable Forward Market for Chinese RMB: A First Look”, China Economic Review, 15, 2004, pp. 348-352.

11. Françoise Lemoine and Deniz Unal-Kesenci, "Trade and Technology Transfers: A Comparative Study of Turkey, India and China", CEPII, Working Paper No. 2003-16. 12. Chen-Yuan Tung and Sam Baker consider that "the net effect on China's terms of trade from even the sort of maxi revaluation that we advocate [15\%] would be modest". Chen-Yuan Tung and Sam Baker, "RMB revaluation will serve China self-interest", China Economic Review, 15, 2004, pp. 331-335.

13. An analytical table of 13 articles providing price-elasticity estimations is given in a previous version of the paper available on the CERDI website as a working paper at http://www.cerdi.org/Publi/ED_Detail.asp?Id=739

14. Jonathan Anderson, “Don't Get So Excited About the Yuan", Wall Street Journal, 2005, July 26 th.

15. Ronald McKinnon, "The East Asian dollar standard", China Economic Review, 15, 2005, pp. 325-330. Joseph Stiglitz, "US has Little to Teach China About Steady Economy", Financial Times, July $26^{\text {th }} 2005$.

16. As explicitly argued by Agnès Bénassy-Quéré and Amina Lahrèche-Revil, "since the direct impact of the yuan on foreign imbalances was expected to be relatively small, the main issue was on whether neighbouring countries would follow a revaluation of the Chinese currency". Agnès Bénassy-Quéré and Amina Lahrèche-Revil, "Trade Linkages and Exchange Rates in Asia: The Role of China”, CEPII, Working Paper No. 21, December 2003.

17. Morris Goldstein, “Adjusting China's exchange rate policies", op. cit.

18. Agnès Bénassy-Quéré and Amina Lahrèche-Revil, op. cit.

19. Agnès Bénassy-Quéré and Amina Lahrèche-Revil, 2003, estimate the elasticity of intra-Asian trade to bilateral exchange rates at 0.5 .

20. Chen-Yuan Tung and Sam Baker, "RMB revaluation will serve China self-interest", China Economic Review, 15, 2004, pp. 331-335.

21. Morris Goldstein, “Adjusting China's exchange rate policies", op. cit.

22. At the $6^{\text {th }}$ Asia-European Union Meeting (ASEM) in Tianjin, June 26th 2005 
23. The difficulty of coping with sterilisation costs is directly linked to the well-known "impossible trinity" identified by Robert A. Mundell, "The Appropriate Use of Monetary and Fiscal Policy under Fixed Exchange Rates", IMF Staff Papers, 1962, No. 09.

24. Eswar Prasad, Thomas Rumbaugh and Qing Wang, "Putting the Cart Before the Horse? Capital Account Liberalization and Exchange Rate Flexibility in China", International Monetary Fund, IMF Policy Discussion Paper, PDP/05/1, January 2005. 25. The yuan is likely to appreciate with a more flexible exchange rate regime. Therefore, from the US point of view, a good reason to advocate greater flexibility is to gain appreciation of the yuan. Obviously, this argument confuses the revaluation and the flexibility debates.

26. Michael Dooley, David Folkerts-Landau and Peter Garber, "An Essay on the Revived Bretton-Woods System", NBER Working Paper No. 9971, Cambridge, September 2003.

27. Fung and al., op. cit.

28. To sum up McKinnon's view, soft pegging on the dollar is an acceptable third best, since the first best (regional common currency) is politically unfeasible in the short run, and the second best (hard pegging) is too risky without regional co-ordination. 29. Morris Goldstein and Nicholas Lardy, "China's Exchange Rate Regime", Wall Street Journal, September 12th 2003.

30. Ding Lu, "China's Capability to Control its Exchange Rate", China Economic Review, 15, pp. 343-347, 2004.

31. John Williamson, "The Choice of Exchange Rate Regime: The Relevance of International Experience to China's Decision", Institute for International Economics, 2004.

32. John Williamson, "A Currency Basket for East Asia, Not Just China", Institute for International Economics, Policy Briefs, PB5-1, August 2005, uses the total trade and excludes countries whose trade with China is smaller than $5 \%$ of the total.

33.According to Krugman's comment, "the statement was terse and uninformative" or even "inscrutable", Wall Street Journal, July 23rd 2005.

34.Dickie Mure, "Renminbi's tight rein a damper on US hopes", Financial Times, July $22^{\text {nd }}$ 2005.

35. Eiji Ogawa, "Chinese exchange rate policy", paper presented at the $1^{\text {st }}$ Conference on Transition and Economic Development in China, Fudan University, September 10th-11 2005.

36. As of April 30th 2005, the de facto exchange rate arrangements in the region were: currency board in the Hong Kong SAR, fixed peg in China and Malaysia, managed floating with no predetermined path for the exchange rate in Indonesia, Thailand, India and Singapore, independently floating in Korea, Philippines, Taiwan and Japan. IMF Annual Report Table II.13.

37. William Jr Pesek, "Unpegging the Ringgit is a Sign of Malaysia's Strength", Bloomberg News, July $28^{\text {th }} 2005$.

38. For instance, the State Information Centre cuts the GDP growth forecast by 0.5 percentage point, a export growth by 1.5 percentage points and inflation by 0.4 percentage point.

39. However, Crédit Agricole-CLSA chief economist Jim Walker expected that economic growth in China will slow in 2006 (in a range of 5\%-7\%) as domestic demand eases and manufacturers continue to face high oil and commodity prices. 
40. Except for the International Monetary Fund that has maintained its prevision of 3.0\% because of a surprising growth in M2 in August, a y-o-y of $+17.3 \%$ compared to a target of $+16.5 \%$ and a July growth of $16.3 \%$.

41. The fight against revaluation pressure may also rely on interventions in the domestic financial system, Huayu Sun and Yue Ma, "Policy strategies to deal with revaluation pressures on the Renminbi”, China Economic Review, Vol. 16(2), pp. 103-117.

\section{RÉSUMÉS}

On July 21st 2005, China slightly revalued the yuan and officially modified the exchange rate system. Interpreting this move as only the outcome of international pressures to reduce international trade imbalances is however misleading. To support our argument, we explore the rationale of the July 21st decision through a review of the twin debates of the exchange rate level / system in China. We argue that both external and internal concerns are taken into account by the Chinese authorities in the management of the exchange rate. Moreover, responsibility for the management of the Chinese exchange rate among the imbalance in world trade is in doubt. The review of recent developments since the July 21st decision shows that its impact is limited. While "hot money" inflows seem to have been tamed, previous economic trends have not yet been modified ${ }^{1}$. 